$$
\begin{array}{r}
\text { 糖蜜，酢酸および酸化カルシウムを用いたカオリン粘土の締固め† } \\
\text { 堤 } \quad \text { 隆 }^{*} \text { 谷口 亮太**内田 修司*** 日高 純三**** }
\end{array}
$$

\title{
Compaction for Kaolin Clay using Molasses, Acetic Acid and Calcium Oxide
}

\author{
by
}

\author{
Takashi Tsutsumi*, Ryota TAniguchi**, Shuji UChIDA*** and Junzo HidaKA****
}

\begin{abstract}
Ground improvement using lime or cement is popular because of the speed, adaptability, and profitability of this method. However, pollution due to alkaline water from lime or hexavalent chromium from cement may occur as a result. To avoid these issues, some studies have been carried out in India and a few African countries on the use of molasses for the improvement of clays. The increase in mechanical strength was demonstrated using the unconfined compressive strength or California Bearing Ratio (CBR) value. However, a sufficient value for ground improvement has not been achieved yet. In the present study, acetic acid and calcium oxide were added into molasses solution to increase the mechanical properties of clay specimens. Throughout the curing period, air temperature was set at $25{ }^{\circ} \mathrm{C}$ and the specimens were placed in a drying furnace. 1, 3, 7 and 28 days were chosen as the curing periods. The Brazilian test was used to obtain the tensile strength value for evaluation of the mechanical properties of the specimens. The tensile strength obtained through this procedure was twice that than from specimens with distilled water and 1.5 times that from specimens treated with a $10 \%$ molasses solution. Furthermore, the dry density achieved through this procedure was larger than that of specimens with distilled water because of the surface activity of molasses. At the same time, it was shown that the $\mathrm{pH}$ value of Kaolin clay treated with the solution proposed in this study is in the range of weak acidity. Therefore, the solution proposed in this study is expected not only improvement in mechanical properties of Kaolin clay but also little load to vegetation in ground improvement.
\end{abstract}

\section{Key words:}

Molasses, Kaolin clay, Acetic acid, Calcium oxide, Soil improvement, Tensile strength, Dry density, $\mathrm{pH}$ value

\section{1 緒言}

我が国においては社会経済活動の基盤となる平野部の 多くが軟弱な粘性土で構成されている. したがって，こ のような場所での建設工事の多くは軟弱な粘性土を取り 扱うことになる．加えて，近年では処分費用の高騰から 建設工事現場から搬出される建設発生土の積極的かつ有 効活用が着目されている. 建設発生土の活用においては, 経済性，施工性のみならず環境面においても社会的要請 を満たさなければならない1)。

地盤の安定処理方法には機械的方法と安定剤の混合に よる方法に大別され，これらのうち後者では地盤に不足 する粒度を補う方法と固結化に分類される ${ }^{2)}$. 粘土に対す る固結化には石灰, セメント系固化材が用いられてきた。 しかしながら，これらの固化材では改良土の $\mathrm{pH}$ 值がアル カリ性を示すため改良土からの表流水や浸透水による植 生などの周辺の環境に影響を及ぼす可能性が指摘されて いる ${ }^{3)}$.さらに，セメントおよびセメント系固化材では，
改良土からの六価クロムの溶出も報告されている4).この ことからも, 十分な力学的強度を発生させるだけでなく, 周辺環境への負荷の小さい地盤安定剤の開発が望まれる. アフリカやインドにおいて, 弱酸性であるさとうきび の糖蜜を使った路床の改良の試みがなされてきた。 M' Ndegwa ${ }^{5) や ~ T a y e ~ ら ~}{ }^{6}$ は膨潤性粘土への, Ravi ら ${ }^{7}$ は圧縮 性粘土への, そして Kiran $5^{8)}$ は黒綿土への安定処理を試 みた。 そこでは一軸圧縮強さや CBR 值などの力学的特性 に改善が見られセメントを用いた改良土に比べ $\mathrm{pH}$ 值が 低いことが報告されているが，実用にあたっては糖蜜の みでは十分な強度増加を得るには至っていない。 廣内ら は, 蟻塚由来のラテライトに酸化カルシウムを混入させ て粒子間の結合力を向上させたラテライトブロックの作 成を試みた ${ }^{9)}$. また, Melese は膨潤性粘土に対し糖蜜に石 灰，バガス灰およびセメントを混ぜ地盤改良を試みた ${ }^{10)}$. 著者らは糖蜜, 酸化カルシウムの他に弱い凝集効果が期 待される微量の酢酸 ${ }^{11)}$ を加えた水溶液でカオリン粘土を

$\dagger \quad$ 原稿受理 令和3年6月6日 Received June 6, 2021 C2022 The Society of Materials Science, Japan

* 正 会 員 鹿児島工業高等専門学校 都市環境デザイン工学科 $7899-5193$ 霧島市隼人町真孝

Dept. Urban Environmental Design and Eng., N. I. T. Kagoshima Col., Hayatochoshinko, Kirishima 899-5193.

** 長岡技術科学大学 工学部 環境社会基盤工学課程 $\bar{T} 940-2188$ 長岡市上富岡町

Dept. Civil and Environmental Eng., Nagaoka Univ. of Tech., Kamitomiokamachi, Nagaoka 940-2188.

**** 福島工業高等専門学校 化学・バイオ工学科 テ970-8034 いわき市平上荒川

Dept. Applied Chemistry and Biochemistry, N. I. T. Fukushima Col., Tairakamiarakawa, Iwaki 970-8034.

***** 合同会社HICD $\bar{\top} 112-0002$ 文京区小石川

HIC Distributing LLC, Koishikawa, Bunkyo-ku 112-0002. 
締固めた。湿潤および気乾を組み合わせた 4 種類の条件 で 7 日間養生を行った後に圧裂試験を行い，締固めに最 適な仕事量および初期含水比を見出した。ここでは，糖 蜜のみの水溶液で締固めた粘土に対し約 1.2 倍の引張強 さを得た ${ }^{12)}$

本論文では，糖蜜，酸化カルシウムおよび酢酸を用い た水溶液で締固めたカオリン粘土の時系列での強度の発 現を観察した。まず，この水溶液を用いてカオリン粘土 の塑性限界，液性限界および塑性指数を求めた。 次に, この水溶液を用いてカオリン粘土を締固め，路床の改良 など短い工期が求められる場合を想定して，すべての養 生期間を気乾とした。養生 1 日，3 日，7 日および 28 日 の引張強さを圧裂試験により求めた。 さらにこれらの養 生日数における初期含水量に対する含水量の比を求め, 圧裂試験に用いた供試体の乾燥密度を求めた。同時に環 境への負荷の指標として含水比が異なる試料ごとに $\mathrm{pH}$ 值を測定した，得られたこれらの結果を蒸留水あるいは 糖蜜のみの水溶液で締固めた供試体から得られた結果と 比較し, 本研究で用いた水溶液の有用性について示した.

\section{2 実 験 方 法}

2.1 粘土試料と水溶液

(1) 用いた粘土試料

本研究では昭和 KDE 社関白 AN クレーを用いた。関白 $\mathrm{AN}$ クレーの密度は $2.65 \mathrm{~g} / \mathrm{cm}^{3}$, 自然状態の含水比は $0.48 \%$ 成分は $\mathrm{SiO}_{2} 63.3 \%, \mathrm{Al}_{2} \mathrm{O}_{3} 18.9 \%, \mathrm{Fe}_{2} \mathrm{O}_{3}$ 0.19\%, $\mathrm{K}_{2} \mathrm{O} 2.9 \%$ で, 粒度分布を Fig. 1 の粒径加積曲線に示寸 ${ }^{12)}$. 関白 AN クレ 一の液性限界，塑性限界はそれぞれ 25.61\%，17.88\%であ る.

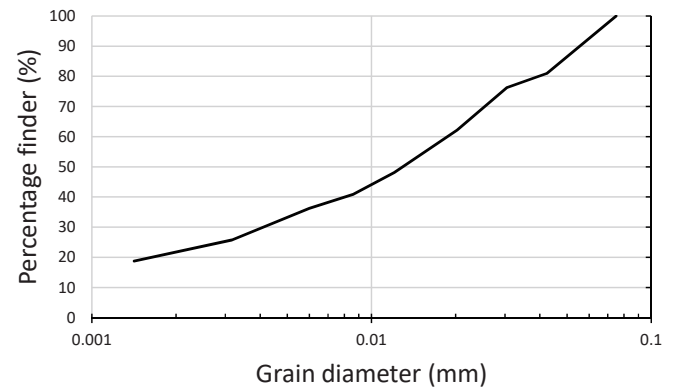

Fig. 1 Grain size accumulation curve of clay used in present study ${ }^{12}$.

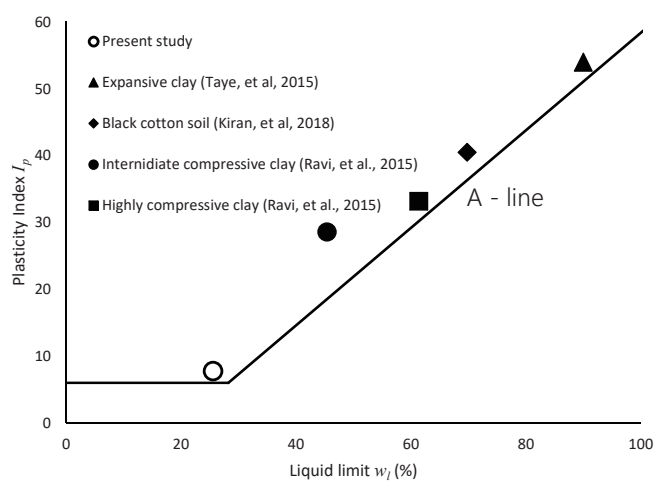

Fig. 2 Consistency of clays used in present and former studies.
Fig. 2 に関白 AN クレーの液性限界と塑性指数を既往の 研究で用いられた粘土試料のものとともに塑性図上に表 す.

(2) 締固めに用いた水溶液

用いた糖蜜は日本ガーリック社製の糖蜜液である。質 量比 $10 \%$ の濃度の水溶液の $\mathrm{pH}$ 值は 5.12 , 水分は $26.80 \%$, ミネラルの含有割合および含有量は Table 1 に示すとおり である ${ }^{12)}$. 酢酸は(株)エヌ・エヌ・シー社製濃度 $90 \%$ のも のを, 酸化カルシウムは林純薬工業(株)製の試薬を用いた.

これらの糖蜜, 試薬を使って Table 2 に示すような 3 種 類の組み合わせの水溶液で締固めた。 D, M はそれぞれ蒸 留水および質量比 $10 \%$ の糖蜜水溶液を表わす。 MCAD に おいては糖蜜の濃度は著者らの先行研究 ${ }^{12)}$ と同じ質量比 $10 \%$ とし, 酸化カルシウムの溶解度は $1.19 \mathrm{~g} / 1^{13)}$ であること から水溶液の酸化カルシウム濃度を $1 \mathrm{~g} / 1$ 程度となるよう 質量比で $0.1 \%$ とした. 䣷酸の濃度は著者らの研究におい て最も大きな引張強さが得られた $0.9 \%$ とした ${ }^{12)}$.

Table 1 Mineral in molasses used in present study ${ }^{12)}$

\begin{tabular}{|c|c|c|c|c|}
\hline \multicolumn{5}{|c|}{ Mineral in molasses (\%) } \\
\hline $\mathrm{Ca}$ & $\mathrm{P}$ & $\mathrm{Mg}$ & $\mathrm{K}$ & $\mathrm{Na}$ \\
\hline 1.19 & 0.11 & 0.47 & 3.17 & 0.37 \\
\hline \multicolumn{5}{|c|}{ Mineral in molasses (mg/kg) } \\
\hline $\mathrm{Fe}$ & $\mathrm{Cu}$ & $\mathrm{Zn}$ & $\mathrm{Mn}$ & $\mathrm{Mo}$ \\
\hline 300.00 & 79.40 & 43.00 & 56.00 & 0.10 \\
\hline
\end{tabular}

Table 2 Variation of solution in present study.

\begin{tabular}{|c|c|c|c|c|}
\hline Solution & Molasses & $\begin{array}{c}\text { Calcium } \\
\text { oxide }\end{array}$ & $\begin{array}{c}\text { Acetic } \\
\text { acid }\end{array}$ & $\mathrm{pH}$ value \\
\hline $\mathrm{D}$ & 0 & 0 & 0 & 6.27 \\
\hline $\mathrm{M}$ & $10 \%$ & 0 & 0 & 5.12 \\
\hline $\mathrm{MCAD}$ & $10 \%$ & $0.1 \%$ & $0.9 \%$ & 4.33 \\
\hline
\end{tabular}

\section{2 力学試験}

著者らの実験によれば，MCAD を用いて湿潤養生を 4 日行った養生日数 7 日で最も大きな引張強さが得られる 初期含水比は, 締固め時に塑性変形が発生しない最も大 きな含水比である $11 \%$ から $12 \%$ 付近である ${ }^{12)}$. 本研究で は初期含水比が同程度になるように, 自然乾燥状態の粘 土試料 $370 \mathrm{~g}$ に対して Table 2 に示す液体を霧吹きで与え 試料を作成した. 直径 $5 \mathrm{~cm}$ 高さ $10 \mathrm{~cm}$ のモールドに厚さ $l$ が $2.5 \mathrm{~cm}$ 程度となるように $90 \mathrm{~g}$ の試料を入れて突き固め, 供試体を作成した。 Proctorによって定義された供試体一 の締固め仕事量 $E_{c}$ を式(1)に示す ${ }^{14)}$.

$$
E_{c}=\frac{W_{R} H N_{B} N_{L}}{V} .
$$

ここに, $W_{R}$ は締固めに用いたランマーの重量, $H$ はラ ンマーの落下高さ， $N_{B}$ は層当たりの突き固め回数， $N_{L}$ は 層の数, $V$ は供試体の体積を表す. 本研究で用いたランマ 一は $W_{R}$ が $14.7 \mathrm{~N}$ (1.5kgf)，H が $20 \mathrm{~cm}$ であり， $N_{L}$ は 1 とし た．著者らの研究によればカオリン粘土に対し最も効果 
が期待できる締固め仕事量は $E_{c}=600 \mathrm{~N} / \mathrm{cm}^{2}$ 程度であるこ と ${ }^{12) か ら ， ~} N_{B}$ を 99 とした。

栘井らが行ったカオリン粘土に対する引張試験 15)では, 飽和状態から自然乾燥させたにもかかわらず引張試験時 の含水比が近い值でありながら引張強さが大きく異なる 供試体が見受けられた。本研究では養生時の環境の変化 をできるだけ小さくするため $25^{\circ} \mathrm{Cに}$ 設定した篠原製作所 60 型循環乾燥機中での空気乾燥とし，期間は $1,3,7$ およ び 28 日とした。養生中は毎日午前 8 時に乾燥機内の湿度 を測定し，それらの平均值は 42.1\%，標準偏差は 8.0\%， 最小值は $25 \%$ ，最大值は $60 \%$ であった。

室内あるいは現場で締固めや化学的処理によって人工 的な改良を加えた土は一軸圧縮強さによって改良の効果 が判定され，改良地盤の安定性が評価される 16)。粘土の 一軸圧縮強さに対する引張強さの比は有明粘土で 0.12 0.13 , 兵庫粘土で $0.18 \sim 0.21$ となるなど, 粘土の一軸圧縮 強さと引張強さには相関があることが示されている ${ }^{17)}$. そこで, 本研究では水溶液の種類による改良の効果を引 張強さで確認した. 用いた試験方法は Fig. 3 に示すような 圧裂試験である。圧裂試験は普及した一軸圧縮試験機を 用いて容易に行うことがでさる利点を有する。ささらに供 試体の成型も容易で, 使用する土試料も少なくてすむ長 所もある. 引張強さ $\sigma_{t}$ は以下の式で与えられる ${ }^{18)}$.

$$
\sigma_{t}=\frac{P}{\pi a l} \text {. }
$$

ここに $P$ は圧縮荷重, $a$ は供試体の半径である. 供試体 の厚さlはノギスを用いて中心から対面の 2 か所を測定し 平均した值を用いた. さらに, 破壊後の供試体の含水比を 測定し, 供試体の乾燥密度を求めた。

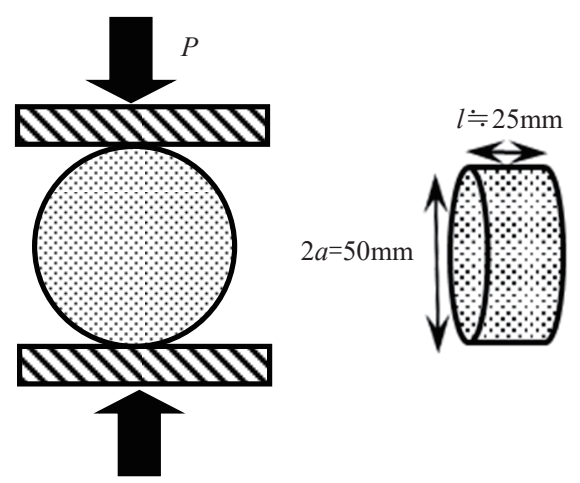

Fig.3 Brazilian test and specimen in present study ${ }^{12}$.

\section{3 結果および考察 \\ 3.1 コンシステンシーの変化}

M および MCAD の液性限界と塑性限界はそれぞれ $24.68 \%$ と $16.17 \%$, 25.45\%と $16.83 \%$ であった。 D で得られ た值を含めてこれらを塑性図上に表すと Fig. 4 のように なる。
Taye らによれば，エチオピアの膨潤性粘土に対しては 糖蜜を質量比で $8 \%$ 混合したときに最も液性限界が小さ くなる ${ }^{6}$. また, Kiran らも黒綿土に対して糖蜜を質量比 $8 \%$ で混合したときに塑性限界，液性限界とも最小になる としている ${ }^{8)}$. 著者らの実験では質量比で $10 \%$ の糖蜜を含 む水溶液を含水比 7\%から $12 \%$ 程度を加えて供試体を作成 したので，粘土に対する糖蜜の質量比は $1 \%$ 程度となる. M では塑性限界, 液性限界とも D の場合に比べ減少して り, Kiran らと同様の結果になった。 MCAD では塑性限 界は減少したものの液性限界は D とほぼ同じ值となった。 石灰処理土は石灰添加量が増加するにしたがって液性限 界, 塑性限界とも減少することが知られており, 特に液 性限界は石灰添加量が $0 \%$ から $5 \%$ までの範囲での減少が 著しい ${ }^{19)}$ 。このことから, MCAD で液性限界の值がほぼ $\mathrm{D}$ に等しかったのは酢酸の効果と考えられる. 同一の液 性限界值を持った粘土では塑性指数が大きいほど乾燥状 態での結合力が大きい 20)ことから, 酢酸の添加による乾 燥時の引張強さ増加への寄与が期待できる.

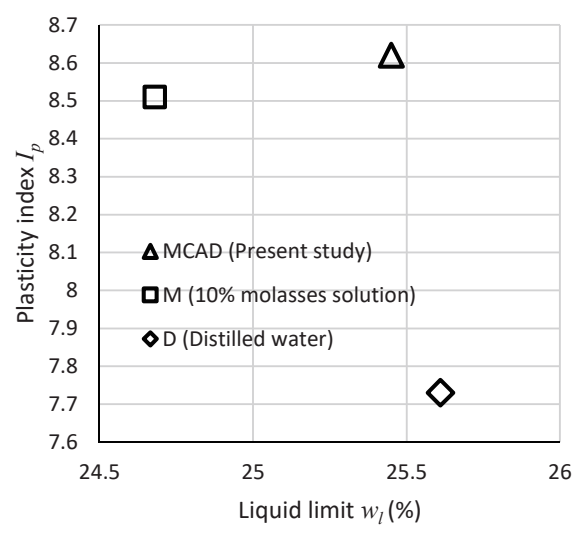

Fig. 4 Coordinates of consistency limits on plasticity chart.

\section{2 引張強さ}

$\mathrm{MCAD}, \mathrm{M}$ および $\mathrm{D}$ の初期含水比と引張強さの関係を Fig. 5 に示す. 以下，養生日数ごとに考察する.

(1) 養生日数 1 日

D では初期含水比が 7.45\%から 11.59\%に増加する間で は引張強さの変化はほとんど見られず，すべて $7.5 \mathrm{~N} / \mathrm{cm}^{2}$ 程度となった。 M では初期含水比が 7.46\%および $10.11 \%$ を除けば初期含水比が大きくなるにしたがって引張強さ も大きくなった．初期含水比が $7.46 \%$ おび $10.11 \%$ で作 成した供試体の養生初日の乾燥機内の湿度が $29 \%$ おび $31 \%$ と著しく低かったことから養生日数 1 日における引 張強さが他の供試体に比べて大きな值となったものと考 えられる. 初期含水比が $12.58 \%$ で作成した供試体も養生 初日の乾燥機内の湿度が $31 \%$ と著しく低かったが, 他の 供試体に比べ初期含水比が高くこの間に蒸発した水分量 の初期含水量に対する比が小さいことから, 養生日数 1 日での引張強さへの影響は小さかったものと考えられる. MCAD でも初期含水比が 7.50\%から 11.63\%となる間に引 張強さは $11.8 \mathrm{~N} / \mathrm{cm}^{2}$ から $17.7 \mathrm{~N} / \mathrm{cm}^{2}$ へと一様に増加した。 


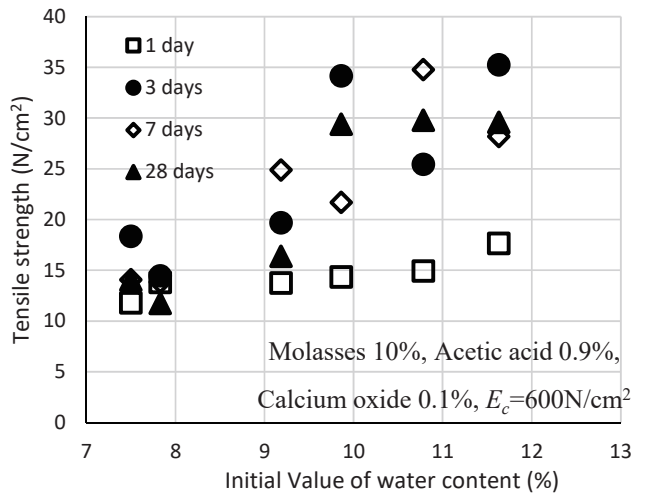

(a) MCAD (Present study)

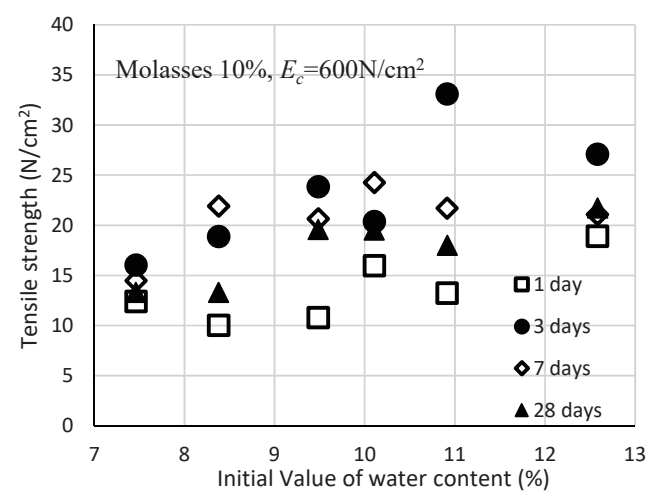

(b) $\mathrm{M}(10 \%$ molasses solution)

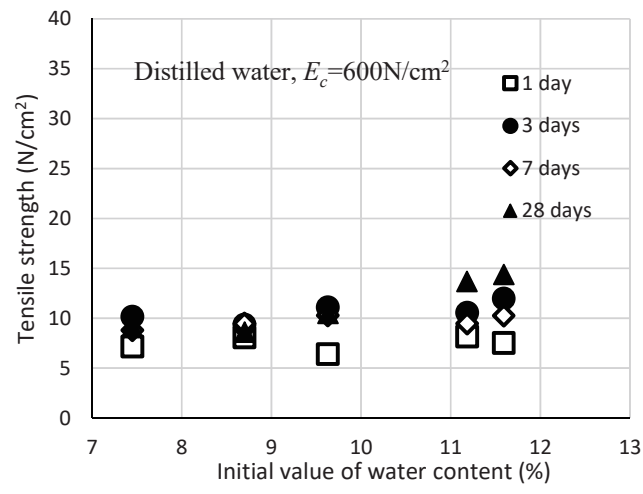

(c) $\mathrm{D}$ (Distilled water)

Fig. 5 Relation between tensile strength and initial water content.

(2) 養生日数 3 日

$\mathrm{D}$ ではやはり初期含水比の増加による引張強さの増加 は小さく，すべて $10 \mathrm{~N} / \mathrm{cm}^{2}$ 程度の值となった。 M では初 期含水比が $10.11 \%$ を除けば $10.92 \%$ までは初期含水比の值 が増加するにしたがって引張強さも増加し, 最大值は 33.1 $\mathrm{N} / \mathrm{cm}^{2}$ を示した。 それを超えると引張強さは減少し, 初期 含水比が $12.58 \%$ ときに $27.1 \mathrm{~N} / \mathrm{cm}^{2}$ となった. MCAD では初期含水比が 7.82\%, 9.19\%および 10.78\%では初期含 水比が増加するにしたがって引張強さも増加した。初期 含水比 $7.50 \%$ の供試体の養生開始後 3 日間の乾燥機内の 湿度は $28 \%, 32 \%, 38 \%$ となり養生初日と 2 日目の湿度が 低いことから養生日数 3 日での引張強さが大きくなった ものと考えられる. 初期含水比 $9.86 \%$ の供試体の養生開始 後 3 日間の乾燥機内の湿度は $34 \%, 26 \%, 37 \%$ で，特に

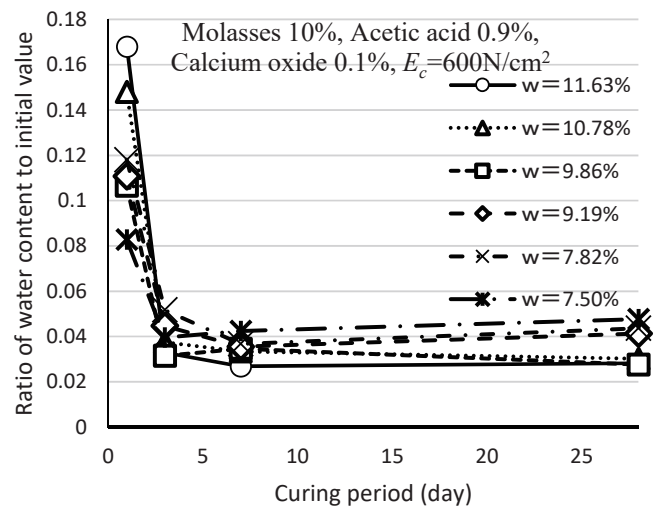

(a) MCAD (Present study)

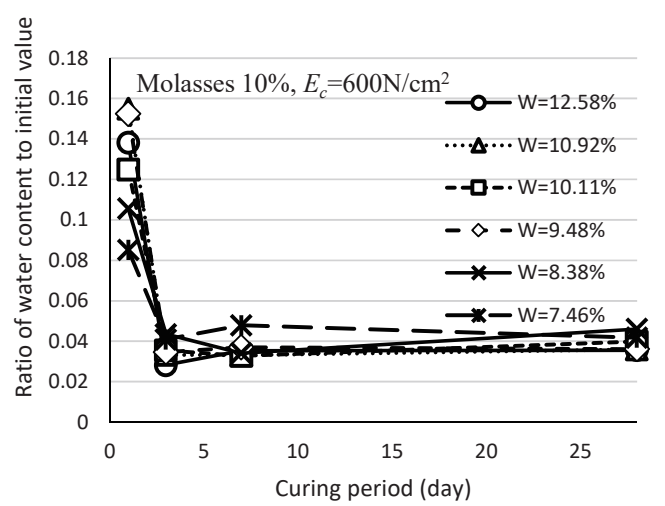

(b) M (10\% molasses solution)

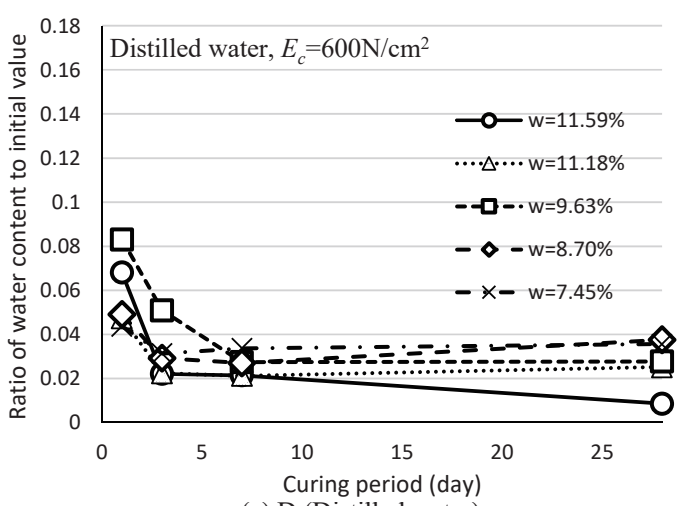

(c) D (Distilled water)

Fig. 6 Water content in specimens during curing period.

養生 2 日目の湿度が小さかったことによって養生日数 3 日での引張強さが大きくなったものと考えられる. 初期 含水比 $11.63 \%$ の供試体の養生開始後 3 日間の乾燥機内の 湿度は $42 \% ， 34 \% ， 26 \%$ で，特に養生 3 日目の湿度が小 さかったことによって養生日数 3 日での引張強さが大き くなったものと考えられる.

(3) 養生日数 7 日

Dではいずれの初期含水比においても養生日数 3 日とほ ぼ同じ引張強さとなった．M では初期含水比が $8.38 \%$ 以 上で $20 \mathrm{~N} / \mathrm{cm}^{2}$ から $25 \mathrm{~N} / \mathrm{cm}^{2}$ 程度の引張強さを示した。 MCAD では初期含水比が $9.19 \%$ と 10.78\% で養生 3 日の引 張強さより大きくなり， 7.52\%，9.86\%，11.67\%で小さく なった。 これについては，養生中の湿度だけでは説明で きず原因の特定には至っていない。 
(4) 養生日数 28 日

D では初期含水比が大きくなるにしたがって引張強さ もわずかながら増加し，初期含水比が $11.59 \%$ のときに最 大值は $14.4 \mathrm{~N} / \mathrm{cm}^{2}$ となった。 $\mathrm{M}$ では初期含水比 $9.48 \%$ 以 上で $20 \mathrm{~N} / \mathrm{cm}^{2}$ 程度の值を示した。 MCAD では初期含水比 9.86\%以上であれば養生日数 1,3 および 7 日における引張 強さ発生の履歴にかかわらず， $30 \mathrm{~N} / \mathrm{cm}^{2}$ 程度のほぼ一定 值となった。

\section{3 含水比の変化}

Fig. 6 は MCAD, M およびDのそれぞれの初期含水比で 作成した供試体での養生日数 1,3,7および 28 日における 初期含水量に対する含水量の比を表す.

糖蜜を含む MCAD およびM は養生日数 1 日での初期含 水量に対する含水量の比が D の 2 倍程度となった。さら に，それ以降も MCAD および M は $\mathrm{D}$ よりも 0.01 程度大 きな值となった. MCAD は酸化カルシウムを含んでおり， 化学反応によって硬化を促進させるために適度な含水量 を含むことは地盤改良に有利に働くことが期待される.

3.4 供試体の乾燥密度

Fig. 7 は MCAD，M および D それぞれの供試体での初 期含水比と養生日数 $1,3,7$ および 28 日での乾燥密度の関 係を表す。いずれの水溶液も締固めにおける最適含水比 には至っていないため, 初期含水比が大きくなるにした がって乾燥密度も大きくなった. D では初期含水比 $11.5 \%$ 付近での養生日数 28 日での乾燥密度が $1.75 \mathrm{~g} / \mathrm{cm}^{3}$ である のに対し，M，MCAD ではそれぞれ $1.81 \mathrm{~g} / \mathrm{cm}^{3}, 1.78 \mathrm{~g} / \mathrm{cm}^{3}$ である，糖蜜には弱い界面活性効果があることから，界

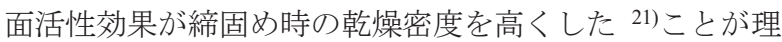
由と考えられる。 また，MCAD では初期含水比が 10.78\% 以上の 2 つの供試体で養生日数 28 日の乾燥密度が養生期 間中で最も小さくなった．本研究で使用したカオリン粘 土の塑性指数は 7.73 であり，仮に膨潤が発生したとして も 0.5 時間から 1.5 時間で終了する 22 ことから膨潤が原因 とは考えられない。酸化カルシウムによる土壤の安定化 は水和反応，イオン交換反応，エトリンガイト生成反応， ポゾラン効果反応，炭酸化反応の 5 つの段階で進行する と考えられている。この中でエトリンガイトの結晶はご く微細な空隙を作りながら成長する ${ }^{3)}$. しかしながら，工 トリンガイトは $\mathrm{pH}$ 值が 10.7 以上で析出され，それ以下 の場合は二水セッコウが析出される ${ }^{23)}$.

Fig. 8 に MCAD，M および D を添加したカオリン粘土 の初期含水比と $\mathrm{pH}$ 值の関係を表す。ここでは，それぞれ の粘土試料について供試体作成時に残った試料を 24 時間 空気乾燥を行った後, $20 \mathrm{~g}$ を採取して $50 \mathrm{cc}$ の蒸留水を加 えて静置したときの上澄み液の $\mathrm{pH}$ 值を採用した. 平均值 はD D M でそれぞれ 4.47 と 4.50 であるのに対し MCAD では 4.88 となった，特に，MCAD では含水比 $11 \%$ 前後で

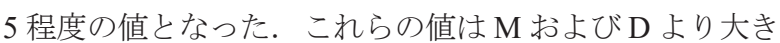
いものの，弱酸性の範囲にあることからエトリンガイト の析出は考えにくい.

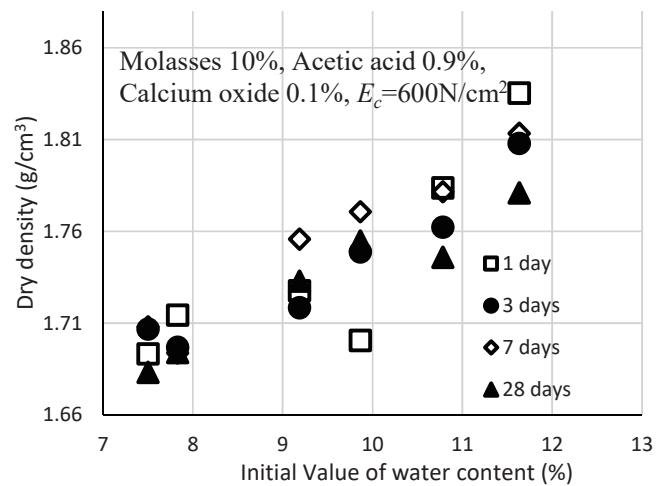

(a) MCAD (Present study)

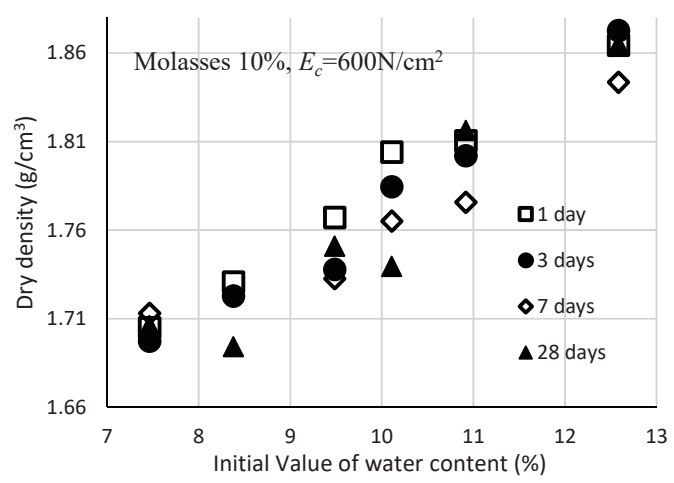

(b) $\mathrm{M}(10 \%$ molasses solution)

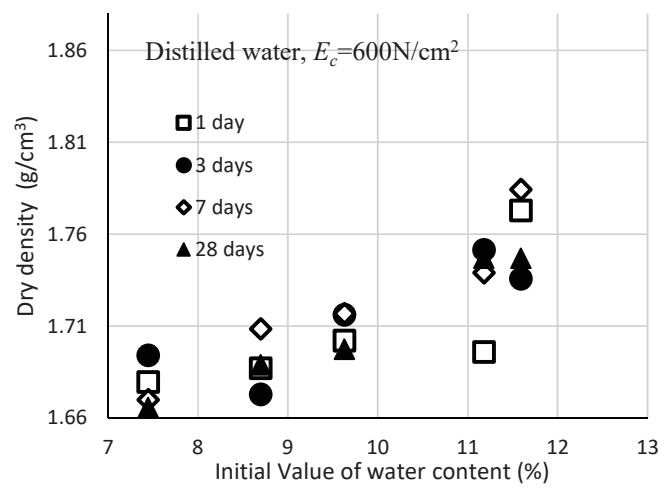

(c) D (Distilled water)

Fig. 7 Relation between dry density and initial water content.

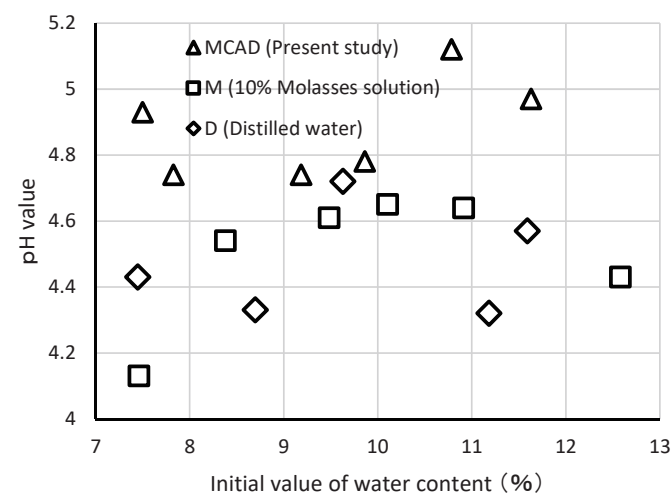

Fig. 8 Relation between $\mathrm{pH}$ value and water content. 


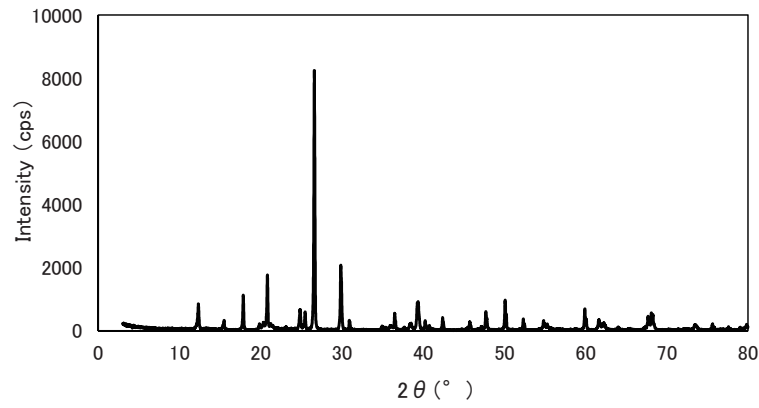

Fig. 9 XRD profile of clay material in present study.

Fig. 9 に本研究で供試体作成に用いた関白 AN クレーの $\mathrm{X}$ 線回折の結果を示す. カオリナイト特有のパターンを 示しており，この図からは不純物として黄鉄鉱などの硫 化鉱物の存在は確認できない 24$)$. Table 1 において糖蜜中 の硫黄の存在に関する記載がないが，これは製造元が硫 黄の成分分析を行っていないことによるもので，硫黄が 存在しないことを意味するものではない. 水/廃糖蜜比 0.5

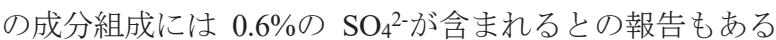
25).

これらのことから，酸化カルシウムと酢酸を含む

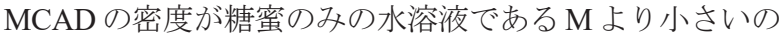
は糖蜜内の $\mathrm{SO}_{4}{ }^{2-}$ と酸化カルシウムとの反応よって二水セ ッコウが析出された際に生じた膨張の可能性が推察され る. MCAD において大きな引張強さが得られた初期含水 比 $11 \%$ 前後の試料で $\mathrm{pH}$ 值が 5 前後と D や M に比べて中 性側の值を示したのも二水セッコウ析出が理由と考えら れる ${ }^{26)}$.

\section{4 結 言}

本研究では質量比で $0.1 \%$ となる酸化カルシウムを含む $10 \%$ の濃度の糖蜜の水溶液に $0.9 \%$ となるように䣷酸を加 えて水溶液を作成し，この水溶液を用いてカオリン粘土 のコンシステンシー限界を求めた。 次に, この水溶液を 用いてカオリン粘土を締固め, 締固め直後より $25^{\circ} \mathrm{C}$ に設 定した循環型乾燥機内で養生を行い， 1, 3, 7 および28 日 後に圧裂試験によって引張強さを求めた。さらに, 試験 後の供試体の含水比を求め, 供試体の乾燥密度およびそ れぞれの初期含水比の試料について $\mathrm{pH}$ 值を求めた. 得ら れた知見は以下のとおりである.

(1) 本研究で提案した水溶液をカオリン粘土に用いた場 合，蒸留水を用いた場合に比べ液性限界はほぼ等しい值 となったが，塑性限界が低くなり塑性指数が増加した。 糖蜜 $10 \%$ 水溶液を用いた場合と比べると, 塑性限界, 液 性限界ともに増加し，塑性指数はほぼ等しくなった.

（2）養生 1 日での引張強さは初期含水比の影響が小さく, 蒸留水を用いた場合に比べ 2 倍程度の值となった. 養生 3 日における引張強さの值は養生時の湿度の影響が見られ， 養生 7 日においても初期含水比の值に対し引張強さは不 規則に発現した。しかしながら，養生日数 28 日では初期
含水比 $10 \%$ 付近を超えると $30 \mathrm{~N} / \mathrm{cm}^{2}$ 程度の一定值を示し た。これは糖蜜 $10 \%$ 水溶液で作成した供試体のほぼ 1.5 倍の值である.

(3) 同じ養生日数で比較した場合, 本研究で用いた水溶液 で作成した供試体は蒸留水で作成したものに比べ初期含 水量に対する含水量の比が高い。これは糖蜜 $10 \%$ 水溶液 で作成した供試体と同じ特徵を示す。

（4）塑性変形を生じさせない最も大きな含水比 $12 \%$ 程度 より低い範囲では，初期含水比が大きくなるにしたがっ て供試体の乾燥密度は大きくなった。 また，本研究で用 いた水溶液で作成した供試体の乾燥密度は蒸留水で作成 したものに比べて高くなった。 さらに糖蜜 $10 \%$ 水溶液で 作成した供試体と比較すると，初期含水比が $7.5 \%$ 付近で はほとんど同じであるが，初期含水比が大きくなるにし たがって糖蜜 $10 \%$ 水溶液で作成した供試体の方が大きく なり，初期含水比 $12 \%$ 付近では $0.3 \mathrm{~g} / \mathrm{cm}^{3}$ 程度の差が生じ た.

(5) 本研究で提案した水溶液で締固めた供試体は初期含 水比 $10 \%$ 超えると養生日数 28 日の引張強さが養生日数 3 日あるいは 7 日よりも小さくなった。 さらに，養生 28 日の乾燥密度も養生期間中の最小となった。

(6) 本研究で提案した水溶液を用いた粘土試料は蒸留水 および糖蜜の夕の水溶液を用いたものと同様に弱酸性で あり, $\mathrm{pH}$ 值は 0.4 程度大きな值を示した。

以上より, 質量比 $10 \%$ の糖蜜のみの水溶液に $0.9 \%$ の酢 酸と $0.1 \%$ の酸化カルシウムを加えて締固めを行ったカオ リン粘土は先行研究で扱われた糖蜜のみの水溶液で締固 めを行った場合に比べて力学的強度が増し, 環境に対し てもほぼ同様に負荷が小さいことが本研究で示された.

この研究を遂行するにあたり，2020 年度鹿児島工業高 等専門学校都市環境デザイン工学科卒業研究においてカ オリン粘土の乾燥に関し多くの示唆に富む知見を導いた 富田凱貴(東洋建設(株)), 本村謙信((株)大阪防水建設社) 両氏に感謝します。 また, X 線回折に関しご協力いただ いた鹿児島県工業技術センター吉村幸雄氏に感謝申し上 げます。

\section{参 考 文 献}

1) T. Kojima, "Soil stabilization with lime", Journal of the Society of Inorganic Materials, No. 14, pp. 355-260 (2007)

2) Y. Asakawa, "Stabilization of soil using lime in soil engineerings", Gypsum \& Lime, No. 138, pp. 32-39 (1975).

3) N. Ozeki, S. Kiriyama and K. Kido, "Soil stabilization with limes and Complexed limes", Journal of the Society of Inorganic Materials, No. 12, pp. 512-515 (2005).

4) T. Hosoya, "Leaching of hexavalent chromium from cementitious soil improvement", Journal of the Society of Material Science, Japan, Vol. 51, No. 8, pp. 933-942 (2002). 
5) J. K. M'Ndegwa, "The effect of cane molasses on strength of expansive clay soil", Journal of Engineering Trends in Engineering and Applied Science, Vol. 2, No. 6, pp. 1034-1041 (2011).

6) B. Taye, and A. A. Araya, "Stabilization of expansive clay soil with sugar cane molasses and cement", Proceedings of 2nd International Conference on Transportation of Africa, pp. 1-12 (2015).

7) E. Ravi, E., A. T. Manikandan, G. Karthick and A. A. Jameel, "Study on effect of molasses on strength of soil", International Journal of Advanced Research Trends in Engineering and Technology, Vol. 2, No. 2, pp. 57-61 (2015).

8) Kiran, S. Harsha, K. V. S. B. Raju and N. M. Kumar, "Experimental study on stabilization of black cotton soil with molasses and arecanut fibers", International Journal of Applied Engineering and Research., Vol. 13, No. 7, pp. 219-223 (2018).

9) S. Hirouchi, H. Horino, H. Dan, C. Hirose, S. Agodzo and P. S. Kwawukume, "Possibility to adapt laterite brick for earth canal protection - A case study in Republic of Ghana -", IDRE Journal, No. 303 (84-3), pp. II_51-II_59 (2016).

10) B. Melese, "Review on soil stabilization using bagasse ash with lime and molasses with cement", Master's thesis of Addis Ababa Science and Technology University, (2018).

11) T. Kida, "Polymers connecting with clay particles", High polymers, Japan, Vol. 13, No. 145, pp. 306-311 (1964).

12) T. Tsutsumi, J. Hidaka and S. Uchida, "Mechanical Behavior of clay compacted with molasses containing acetic acid and calcium oxide", Proceedings of $14^{\text {th }}$ Symposium on Ground Improvement, Japan, pp. 233-238 (2020).

13) H. Takahashi and H. Kimura, "Fundamental research of traditional glazes using raw materials from Ishikawa Prefecture", Research Report of Industrial Research Institute of Ishikawa Prefecture, No. 65, pp.43-46 (2016).

14) Japan Geoengineering Society, "Methods and explanation for soil testing", p. 256 (2000).

15) T. Masui, S. Yao, A. Ito, M. Goto and Y. Sasaya, "The relationship between bonding forces and the state of water in Kaolin clay - Part 1 Experiments for measurement of tensile strength of Kaolin clay-", The proceedings of 37th Japan Geoengineering Society Annual Conference, pp. 935-936 (2002).

16) Japan Geoengineering Society, "Methods and explanation for soil testing", p. 430 (2000).

17) A. Takakura, Y. Koga, A. Hamatake and H. Koga, "Strength properties of stabilized soil slab in road on soft ground", Report of the Faculty of Science and Engineering, Saga University, Vol. 32, No. 2, pp. 17-20 (2002).

18) S. Moriguchi, "Two dimensional elasticity", Iwanami Pub., p. 41 (1956).

19) M. Aoki and A. Tsuji, "Property of compaction for lime-treated soil", Journal of the Agricultural Engineering Society, Japan, Vol. 48 No. 4, pp.251-254 (1980).

20) H. Shirozu, "Clay mineralogy", Asakura Pub., p. 52 (1988).

21) T. Niiro, Y. Masada, J. Jiang and E. Kuribayashi, "Effect of Gas-liquid interfacial forces on compaction behaviors of unsaturated soil", Transaction of Japan Society of Civil Engineering, No. 582/III-41, pp. 265-274 (1997).

22) Y. Shiraki, "Imbibitional swelling properties of clay-water system. Studies on clay-water system, III-6.", Journal of Ceramics Association, Japan, Vol. 72, No. 9, pp. 155-163 (1964).

23) A. Gabrisova and J. Havlica, "Stability of calcium sulphoaluminate hydrates in water solution with various pH values", Cement and Concrete Research, Vol. 21, pp. 1023-1027 (1991).

24) M. Ichikuni, S. Aizawa, K. Yoshikawa, N. Kato and D. Otani, "Production of Yunohana sinter with the use of Kaolinite clay in the Myoban aria, Beppu hot springs", Journal of Hot Spring Science, Vol. 62, pp. 3-12 (2012).

25) H. Ando, T. Otani, I. Furukawa, J. Kamizono and I. Mukoyoshi, "Separation technology of potassium from molasses", Research Report of Industrial Research Institute of Kagoshima Prefecture, No. 29, pp. 19-23 (2015).

26) Y. Umetsu, "Gypsum from Neutralization of sulfuric acid solution with limestone", Gypsum \& Lime, No. 234, pp. 299-305 (1991). 